UDC 005.932: [339.138]: 339.14

JEL: M31, P23, Q02

\section{Mykola Tarakanov}

$\mathrm{PhD}$., Senior research, Department of market mechanisms and structures, Institute of Market Problems and Economic ecological research of the NAS of Ukraine, Odessa, Ukraine

E-mail:tarakanovnikolajenidovic@gmail.com orcid.org/0000-0002-3827-2373

\section{Tetiana Lozova}

Junior research employee, Department of market mechanisms and structures,

Institute of Market Problems and Economic ecological research of the NAS of Ukraine, Odessa, Ukraine

E-mail: ua.lozovaya@gmail.com orcid.org/0000-0002-4896-1930

\section{Ivan Uzun}

$\mathrm{PhD}$., Associate Professor, Department of Economic Theory and World Economy, Transnistria State University, Tiraspol, Pridnestrovian Moldavian Republic E-mail: uzun@spgn.ru orcid.org/0000-0003-4572-4363

Received: April, 2020 Accepted: August, 2020

DOI:10.31520/2616-7107/2020.4.3-2

(C) Economics. Ecology. Socium, 2020 CC BY-NC 4.0 license

\section{INTEGRATED APPROACH TO THE USE OF LOGISTICS AND MARKETING IN THE SYSTEM OF COMMODITY MARKETS}

Introduction. In the conditions of deepening crisis phenomena in economics the problem of increasing efficiency of use of logistic tools in development in the commodity markets is actualized. In particular, this issue is becoming more relevant in relation to perishable food markets, which provide for the coordinated interaction of the components of trade in combination with in-depth consideration of consumer demand.

Aim and tasks. The purpose of the research is to substantiate the methodological approach to the impact of the integration model of logistics marketing on the effectiveness of reproduction processes in the system of commodity markets. The main objectives of the study are: to determine the essence of the interaction of logistics and marketing at the level of commodity markets, substantiation of the phased scheme of eliminating problem areas as part of the leading characteristics of commodity markets, outlining the impact of integrated logistics marketing model on the theoretical foundations of commodity markets.

Results. With the proposed methodological approach to the use of an integrated model of logistics marketing becomes relevant to situations that are associated with radical transformational shifts in the strategic commodity markets associated with the diversification of foreign markets, the formation of complete supply chains, innovative economic development. etc. The proposed scheme of overcoming the problematic characteristics of certain types of commodity markets indicates the presence of significant reserves for the use of marketing research on the formation of effective logistics chains in the system of reproductive processes of trade.

Conclusions. It is concluded that the main indicators of the effectiveness of taking into account the logistical factor in making marketing decisions are determined - the factor of availability of goods for use, accessibility to the place of use and time of use of goods. The influence of marketing on the formation of logistics chains of the commodity market is determined by the adaptation of logistics to the leading characteristics of commodity markets.

Keywords: logistics marketing, commodity market, product market characteristics, typical logistics regime, integration approach. 
УДК 005.932: [339.138]: 339.14

JEL: M31, P23, Q02

\author{
Микола Тараканов \\ к.е.н., с.н.с. \\ відділу ринкових механізмів та \\ структур \\ Інститут проблем ринку та економіко- \\ екологічних досліджень НАН України, \\ Одеса, Україна \\ E-mail:tarakanovnikolajenidovic@gmail.com \\ orcid.org/0000-0002-3827-2373
}

\section{Тетяна Лозова}

молодший науковий співробітник відділу ринкових механізмів та структур

Інститут проблем ринку та економікоекологічних досліджень НАН України, Одеса, Україна

E-mail:ua.lozovaya@gmail.com orcid.org/0000-0002-4896-1930

\section{Іван Узун}

к.е.н., доцент кафедри економічної теорії та світової економіки Придністровський державний університет, Тирасполь E-mail:uzun@spgn.ru orcid.org/0000-0003-4572-4363

Отримано: Квітень, 2020 Прийнято: Серпень, 2020

DOI:10.31520/2616-7107/2020.4.3-2

(C) Економіка. Екологія. Соціум, 2020 CC BY-NC 4.0 ліцензія

\section{ІНТЕГРАЦІЙНИЙ ПІДХІД ДО ВИКОРИСТАННЯ ЛОГІСТИЧНОГО МАРКЕТИНГУ В СИСТЕМІ ТОВАРНИХ РИНКІВ}

Вступ. В умовах поглиблення кризових явищ в економіці актуалізується проблема підвищення ефективності використання логістичних інструментів у розвитку товарних ринків. Підвищену актуальність набуває дане питання по відношенню до ринків швидкопсувних продовольчих товарів, які передбачають узгоджену взаємодію складових товароруху в сполученні 3 поглибленим врахуванням споживчого попиту.

Мета i завдання. Метою дослідження $\epsilon$ обгрунтування методологічного підходу до впливу інтеграційної схеми логістичного маркетингу на результативність відтворювальних процесів в системі товарних ринків. Основними завданнями дослідження є: визначення сутності взаємодії логістики та маркетингу на рівні товарних ринків, обгрунтування поетапної схеми усунення проблемних областей в складі провідних характеристик товарних ринків, окреслення впливу інтегрованої моделі логістичного маркетингу на теоретичні засади типології товарних ринків.

Результати. Запропонований методологічний підхід до використання інтегрованої моделі логістичного маркетингу набуває актуальності до ситуацій, які пов'язані 3 кардинальними трансформаційними зрушеннями у складі стратегічних товарних ринків, пов'язаними 3 диверсифікацією зовнішніх ринків збуту продукції, формуванням завершених ланцюгів товарних постачань, інноваційним розвитком пріоритетних видів економічної діяльності та ін. Запропонована схема подолання проблемних характеристик окремих типів товарних ринків свідчить про наявність суттєвих резервів щодо формування ефективних логістичних ланцюгів в системі відтворювальних процесів товароруху.

Висновки. основними показниками ефективності врахування логістичного фактору на прийняття маркетингових рішень визначені - фактор доступності товару до користування, доступність до місця користування та часу користування товаром. Вплив маркетингу на формування логістичних ланцюгів товарного ринку визначається адаптацією логістики до провідних характеристик товарних ринків.

Ключові слова: логістичний маркетинг, товарний ринок, характеристика товарного ринку, типовий логістичний режим, інтеграційний підхід. 
Introduction. Generally the problem of logistics marketing is aimed at ensuring the effective movement of inventory through the links of logistics chains in combination with the commercial success of the sale of goods [1]. Modern conditions of market relations encourage to pay more attention to the search for additional reserves to improve the efficiency of commodity markets. A relatively new reserve in solving this problem is the integration of logistics and marketing into a single mechanism in the commodity market system, aimed at ensuring an expanded reproductive process of trade and maximizing gross value added [2]. The conceptual representation of the integration approach takes the following form: $\mathrm{LM}=$ [marketing component $(\mathrm{M}+\mathrm{L})+$ logistics component $(\mathrm{L}+\mathrm{M})]$. In this version, the problem area is the disclosure of the essence of the common areas of logistics and marketing both at the stage of logistics development and at the stage of marketing decisions. Disclosure of the essence of each of the components of interaction will allow to systematically characterize their impact on trade, to introduce effective measures for the interaction of logistics chains, to determine promising areas of sales and more.

Literature review. DJ Bowersox [3], M Christopher [4, 5], M. Lindera [6], D. Lambert [7], L. Mirotin [8], A. Gadzhinsky [9], E. Krykavsky [10, 11], N. Chukhrai [12], M. Oklander [13] and other scientists analyzed the research of theoretical-methodological and methodological issues of the interaction of logistics and marketing. In the most complete form, the options for the relationship between logistics and marketing were considered by $\mathrm{E}$. Krykavsky. He singles out: logistics as an integral part of distribution in the marketing complex; marketing as an integral part of the logistics of a manufacturing enterprise; marketing, which is considered through the prism of logistics; marketing and logistics as equal functional strategies; common areas of marketing and logistics [11].

In the research of logistics marketing, insufficient attention is paid to determining the essence of the manifestation of common areas of logistics and marketing in the system of the reproduction process at the level of the commodity market.
This means the separation of an additional stage of research, which prevents the search for options for supply and sale of goods at the level of individual commercial solutions. An additional stage is to make interconnected decisions in the system of logistics marketing in relation to the structural parameters of commodity markets. At the stage of marketing decisions, the impact of logistics is to take into account the logistical conditions of segmentation of consumer demand. In turn, the influence of marketing on the formation of logistics chains of goods movement takes into account the leading characteristics of markets and their types in the process of determining the structural parameters of commodity flows [14].

The purpose of the article is the development of a methodological approach to the impact of the integration model of logistics marketing on the reproductive processes of trade in the commodity market.

Presentation of the main research material. An integral part of the integration approach to the use of logistics marketing is to take into account the logistics factor in the marketing decision-making process $(\mathrm{M}+\mathrm{L})$. To assess the effectiveness of the flow, such indicators as volumes, flow nomenclature, geographical boundaries of the flow are used. Most of the marketers compare the above indicators, including with the target focus on sales [15]. This point of view is logical, because, for example, the same indicator of the quality of the flow of goods or the indicator of the product range affects the effectiveness of sales.

Without objectively rejecting the existing relationship between the above indicators of the logistics chain and sales performance, we note that this relationship does not take into account the impact of logistics on sales parameters in the overall commodity market. To address this issue, it is proposed to consider the influence of the logistics factor on the process of microsegmentation of consumer demand [16]. Microsegmentation radically changes the existing point of view in marketing, according to which consumer demand is created by "economic man", i.e. a man who responds equally to price fluctuations, changes in product range, behaves rationally when buying goods, seeking to maximize benefits and minimize costs. has no gender, status, nationality. 
As such, logistics chains focus on indicators which do not take into account the different reactions of consumers depending on the social aspects of behavior. At the same time, the concept of microsegmentation creates an additional slice in the parameters of logistics chains, which should influence the differentiated behavior of consumers: to the product (the formation of permanent consumer groups); to motivations for purchasing goods (benefits of acquisition); to the values of the acquisition of goods (traditions, prestige, etc.) (Fig. 1).

The issue of microsegmentation of commodity markets by homogeneous commodity groups is considered to be interrelated with the factor of diversity of consumer behavior. Modern theory of competition does not give a clear answer to the signs by which it is necessary to separate homogeneous groups of goods. It only states that homogeneous groups of goods form a competitive environment [17]. As a result, the grouping of goods into product groups is most often carried out on the basis of a generalized name, for example, bakery products, cars, computers, and so on. At the same time, practice shows that in most cases, generalized product groups do not create a competitive environment.

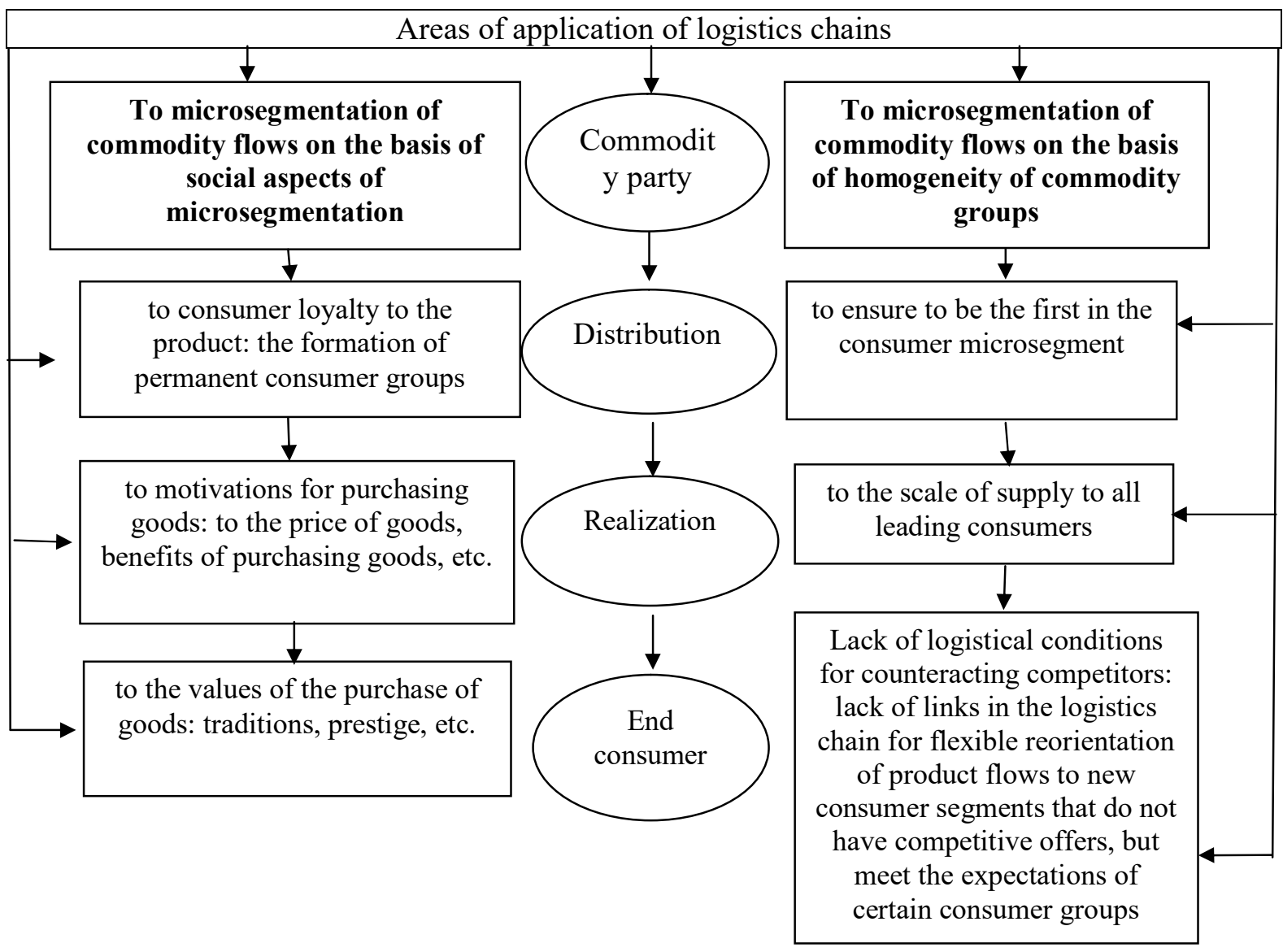

Fig. 1. Potential areas of consideration of the logistics factor in the process of microsegmentation of commodity markets

Source: author's development

As a rule, competitive relations are manifested at the level of subspecies of generalized groups, in which the goods have approximately the same consumer properties. For example, in the generalized group of bakery products homogeneous goods on the basis of competitive relations are grouped into microsegments of bakery products (sliced, not sliced, gray, white bread, etc.), bakery products (bun with jam, without jam, bagels), delicatessen products (pita bread, bread sticks), etc. 
The task of the impact of logistics on subspecies of product groups is to increase their competitiveness in accordance with consumer behavior [18]. As a generalized indicator of the impact of logistics on the product range, we consider the availability of the product group to the consumer market (Acpg), which in turn is differentiated by the availability of the product group (Apg), accessibility to the place of use of the product group (Apou), availability use of product group in time (Apgit):

$$
\text { Acpg }=\text { Apg }+ \text { Apou }+ \text { Apgit }
$$

Availability for use of goods by the group (Apg) is determined by the compliance of goods with the requirements of supply, in particular, the requirements for the use of advanced transport and technological systems: container, roller, packaged, etc. Availability provides adaptation of parameters of a link of deliveries (a link of transportation of the goods) to modern technologies of support of the set consumer properties of the goods in the course of commodity movement, in particular: dimensions, weight characteristics, conditions of intermediate storage of goods, etc.

Availability to the place of use of the goods (Apou) is determined by the properties of the goods, adapted to the places of consumption. Support in providing this condition can be provided by the logistics system "7R", which sets individual parameters of product flows, inherent in the requirements of each local place of consumption: the required product (right product) in a given quantity (right quantity), the required quality (right quality), supplied in time (right time) to the required place (right place) to the required consumer (right customer) with the required level of costs (right cost).

In this system, the use of the services "necessary place" (right place) and "necessary consumer" (right customer) becomes important.

The service "required place" (right place) means a relatively separate local place of demand, within each of which there is a "necessary consumer", which in turn has special requirements for other services: service "set quantity of goods" (right quantity), service "required quality of goods" (right quality), service "delivery time" (right time), service "required level of costs" (right cost).

Availability of time of use of the goods (Apgit) - the logistical component of optimization of the commodity nomenclature is especially important. Its effectiveness is determined by the delivery time of the goods to the final consumer. The maximum volume of commodity turnover in the market is provided in the period during which the highest consumer interest in the product is maintained. Consumer satisfaction during peak demand is achieved by optimizing supply routes, intensification of loading and unloading operations, etc. Therefore, the reduction of this part is an important reserve to minimize the time of delivery of goods to the consumer.

A promising instrument of the influence on the marketing component on the formation of parameters of logistics chains $(L+M)$ is the use of standard logistics modes (SLM) - type sets of parameters of logistics chains, adapted to the leading characteristics of types of commodity markets [19].

It is proposed to implement SLM by focusing on the problematic characteristics of markets (characteristics that do not meet the parameters of logistics chains, which leads to a deterioration of the conditions of expanded reproduction of trade and hinders the process of increasing gross value added in the market). The sequential scheme of use of typical logistic modes is presented in table 1 .

SLM "local trade flow" (type of local markets) has the following characteristics:

- maximum proximity of producers to end consumers, which promotes the use of direct supply in the mode of "local producer local retail network - local end consumer";

- functioning of markets under the influence of limited demand;

- the presence of local traditions of production and consumption, which ensures the relative stability of the product range and sales;

Among the listed characteristics it is necessary to separate a problematic characteristic discrepancy of parameters of logistics chains to local borders of the markets. 
Table 1. Sequential scheme of using typical logistics modes *

\begin{tabular}{|c|c|c|}
\hline 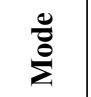 & 总 & Contents of stages \\
\hline \multirow{6}{*}{ 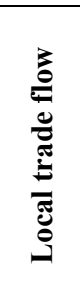 } & $1 \mathrm{st}$ & Type of markets: local commodity markets. \\
\hline & $2 \mathrm{nd}$ & $\begin{array}{l}\text { Leading characteristics: limited borders by territorial factor (usually within cities and adjacent administrative } \\
\text { districts); maximum approximation of producers to end consumers; relative stability of market parameters } \\
\text { under the influence of limited demand and stable local traditions. }\end{array}$ \\
\hline & 3rd & Problem characteristic: inconsistency of parameters of logistics chains with local borders of markets. \\
\hline & 4th & $\begin{array}{l}\text { Measures (targets) to eliminate the problem characteristics: development of supply standards in } \\
\text { combination with the optimization of the number of links in the logistics chain. }\end{array}$ \\
\hline & 5 th & Effects: increase level of local demand. \\
\hline & 6th & Influence on theoretical positions of functioning of this type of markets: not specified. \\
\hline \multirow{6}{*}{ 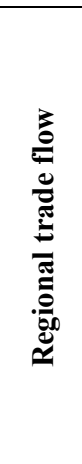 } & $1 \mathrm{st}$ & Market type: regional commodity markets. \\
\hline & 2nd & $\begin{array}{l}\text { Leading characteristics: decisive role in the formation of commodity specialization region; increased the } \\
\text { impact of the external environment on the functioning of markets: investment climate, conditions of } \\
\text { entrepreneurial activity, available labor resources; increased value of spatial indicators of markets: spatial } \\
\text { density of market participants, topological connectivity of the market and so on. }\end{array}$ \\
\hline & $3 \mathrm{rd}$ & $\begin{array}{l}\text { Problem characteristic: low level of topological connectivity of trade between the leading centers of regional } \\
\text { markets and their peripheral zones. }\end{array}$ \\
\hline & 4th & $\begin{array}{l}\text { Measures (targets) to eliminate the problem characteristics: creation of networks of regional logistics } \\
\text { centers for end-to-end planning of trade flows on the basis of interterminal organization of trade }\end{array}$ \\
\hline & 5 th & Effects: formation peripheral logistics centers. \\
\hline & 6th & $\begin{array}{l}\text { Influence on the theoretical provisions of the functioning of this type of markets: } \\
\text { supplementing the theory of regional markets with provisions to ensure the simultaneous development of the } \\
\text { pole and the periphery of the markets; refutation of the assertion of the absence of homogeneous regional } \\
\text { markets as a result of the creation of a polycentric market space. }\end{array}$ \\
\hline \multirow{6}{*}{ 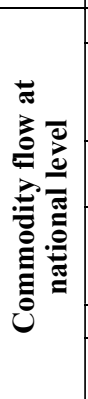 } & $1 \mathrm{st}$ & Market type: national commodity markets. \\
\hline & 2nd & $\begin{array}{l}\text { Leading characteristics: state regulation of reproduction processes at the level of strategic markets; increased } \\
\text { influence on the functioning of markets of foreign economic factors: international competition, protectionist } \\
\text { measures, etc.; connection with regional and local markets. }\end{array}$ \\
\hline & $3 \mathrm{rd}$ & $\begin{array}{l}\text { Problem characteristic: lack of a cross-cutting link in the distribution of commodity supplies at the national, } \\
\text { regional and local levels. }\end{array}$ \\
\hline & 4 th & $\begin{array}{l}\text { Measures (targets) to eliminate the problem characteristics: creation of interconnected networks of logistic } \\
\text { crossroads for complex maintenance of distribution of commodity flows, the basis of which should be a } \\
\text { mechanism of end-to-end planning between national, regional and local levels of trade. }\end{array}$ \\
\hline & 5-th & Effects: elimination of disparities between consumer demand and commodity supplies. \\
\hline & 6th & $\begin{array}{l}\text { Influence on theoretical positions of functioning of this type of markets: relationship with regional and local } \\
\text { spatial type of markets in terms of distribution of commodity supplies. }\end{array}$ \\
\hline \multirow{6}{*}{ 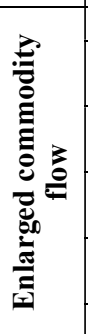 } & $1 \mathrm{st}$ & Market type: mass demand markets. \\
\hline & 2nd & $\begin{array}{l}\text { Leading characteristics: availability of various product nomenclature; a wide range of modes of purchase and } \\
\text { sale of goods (daily, seasonal, long-term use, etc.); high density of suppliers and consumers. }\end{array}$ \\
\hline & $3 \mathrm{rd}$ & $\begin{array}{l}\text { Problem characteristic: a wide range of modes of purchase and sale of goods (daily, seasonal, long-term use, } \\
\text { etc.); }\end{array}$ \\
\hline & 4th & $\begin{array}{l}\text { Measures (targets) to eliminate the problem characteristics: organization of a centralized supply } \\
\text { management system with the help of public distribution centers. }\end{array}$ \\
\hline & 5 th & $\begin{array}{l}\text { Effects: the possibility of using a package of methods of planning the movement of groupage batches of } \\
\text { products, adapted to the unstable conditions, seasonality of demand, etc. }\end{array}$ \\
\hline & 6th & Influence on the theoretical provisions of the functioning of markets: not specified. \\
\hline \multirow{6}{*}{ 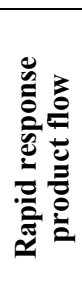 } & $1 \mathrm{st}$ & Market type: saturated markets (markets with manifestations of short-term unsatisfied demand). \\
\hline & 2nd & $\begin{array}{l}\text { Leading characteristics: limited existence of unsatisfied demand; difficulties predict both the beginning of the } \\
\text { manifestation of demand and its completion; insignificant volumes of demand at a high level of spatio-temporal } \\
\text { localization. }\end{array}$ \\
\hline & 3rd & Problem characteristic: limited existence of unsatisfied demand. \\
\hline & 4th & $\begin{array}{l}\text { Measures (targets) to eliminate the problem characteristics: development of mobile chain networks, use of } \\
\text { WMS management systems - solutions, monitoring of short - term unsatisfied demand. }\end{array}$ \\
\hline & 5 th & Effects: combination in time parameters of product supply to the market with the onset of short-term demand. \\
\hline & 6th & Influence on the theoretical provisions of the functioning of markets: not specified \\
\hline \multirow{6}{*}{ 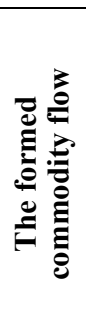 } & $1 \mathrm{st}$ & Market type: potential markets (more market-oriented). \\
\hline & 2nd & $\begin{array}{l}\text { Leading characteristics: significant costs to create market infrastructure; fixed terms of existence of market } \\
\text { niches from deliveries of trial commodity parties before the market niches reach the level of satisfaction of } \\
\text { consumer demand; priority role of logistics in the effectiveness of market development. }\end{array}$ \\
\hline & 3rd & Problem characteristic: priority influence of logistics on the effectiveness of market development. \\
\hline & 4th & $\begin{array}{l}\text { Measures (targets) to eliminate the problem characteristics: involvement in the development of market } \\
\text { niches of logistics providers, the scale of which corresponds to the parameters of market niches; delivery } \\
\text { through centralized logistics channels. }\end{array}$ \\
\hline & 5 th & Effects: effective output of the flow of goods at the level of consumer demand. \\
\hline & 6th & Influence on the theoretical provisions of the functioning of markets: not specified. \\
\hline
\end{tabular}

Source: author's development 
The target of overcoming the discrepancy should be the development of supply standards in combination with the optimization of the number of links in the supply chain. For example, this discrepancy exists in the local markets for natural food products, due to the lack of capacity to produce and supply natural raw materials (milk, etc.) to industrial consumers, which creates unsatisfied demand for natural products.

SLM "Regional trade flow" (regional commodity market) represents a spatially separated part of the national commodity market, the reproductive cycle of trade in which is limited mainly to the regional level. The leading characteristics of regional commodity markets include:

- decisive role in the formation of commodity specialization of the region (markets that form goods specialization of the region is characterized by: a) the excess of production of goods in comparison with the needs of the region in this type of product; $b$ ) active inclusion of the regional commodity market in interregional trade; c) the presence of a developed market infrastructure;

- increased the impact of the external environment on the functioning of markets: the investment climate in the region, business conditions, available labor, etc.;

- increased value of topological indicators of market functioning: spatial density of market participants, levels of economic development of market parts, etc.

The latter characteristic creates an objective prerequisite for the manifestation of the problem situation, which is lack of logistical connection between regional consumer centers and peripheral areas of commodity supply. To solve the problem, it is proposed to create regional networks for endto-end planning of commodity flows on the basis of interterminal organization of trade [20]. This will allow in relation to the type of regional markets in a new way to consider the existing theoretical model of relations "centerperiphery" by transforming it into an extended scheme of relations "market center - a network of peripheral market centers".
This transformation concerns the theory of poles of economic growth, which is leading in determining the patterns of concentration and distribution of business activity within regional markets [21]. In the proposed paradigm "market center - a network of peripheral market centers" the vector of business activity changes to the "leveling" direction, when the market potential becomes more "equilibrium" in the typological structure of the regional market.

To the theoretical innovations should be included:

- supplementing the theory of poles of economic growth with a vector of target orientation to ensure accelerated growth of the pole periphery;

- refutation of the theoretical allegations of the absence of homogeneous regional markets as a result of the creation of a polycentric market space.

SLM "national level commodity flow" (type of markets at the national level) is a spatial system of trade both within the country and in the relations of markets with foreign markets. The leading characteristics of markets of this type include:

- priority of the state levers of regulation of reproduction processes, first of all, at the level of strategic markets, namely: development of programs of the state support of the markets, projects of attraction of investments, tariff regulation of the markets, etc .;

- increased influence on the functioning of markets of external factors, in particular: international competition, protectionist measures, integration processes, etc.;

- interaction with regional and local components of markets.

The last of these characteristics is problematic. The consequence of this situation are cases of simultaneous manifestation in some regions of the trade surplus, in others - its deficiency. To address this issue, it is proposed to create interconnected networks of logistics intersections [22] for comprehensive maintenance of trade flows at the above levels of equal trade. 
The unifying basis of logistics intersections should be the mechanism of endto-end planning of the distribution of goods flows from the highest (national) to the lowest (local) level on the principle of mutually agreed parameters of trade.

Theoretically, the proposed measures form an additional provision for the functioning of this type of markets - the presence of a fruitful relationship with regional and local spatial types of markets in terms of distribution of commodity supplies.

SLM "consolidated trade flow" (type of mass demand markets) forms the following set of characteristics:

- availability of various product nomenclature;

- a wide range of modes of purchase and sale of goods (daily, seasonal, long-term use, etc.);

- high density of suppliers and consumers.

Problematic is the characteristic associated with a wide range of modes of purchase and sale of goods (daily, seasonal, long-term use, etc.). In particular, the seasonal modes of purchase and sale include the market of fruit and berry products.

The fruit and berry market is one of the fastest growing agri-food markets in the country. First of all, this applies to berry products [23]. Despite the fact that its share in the gross volume of agricultural production is $4 \%$, the annual production of berries increases by $10-15 \%$ [24]. According to the forecasts of market experts, this figure can be increased to $25 \%$ per year, because absolutely all types of berries are profitable to grow. According to expert estimates, from 20 hectares of land set aside for berries, farmers receive 4-5 million UAH profit per season [24].

At the same time, the problematic characteristic of the market is an underdeveloped network of sales channels, which is due to the low level of logistics services for the flow of fruit and berry products.

At present, there are four main types of sales channels [25].
1. The "geather yourself" channel requires the least labor costs from the manufacturer to organize the geathering and sale of products. Clients perform a significant proportion of functions on their own, including finding customers. In particular, this channel is effective for berries that are purchased in large quantities for home harvesting.

2. Channel "sales from the field" is the main channel for the sale of fruit and berry products. Its variety is the sale of products through food markets, as well as through roadside sales, provided the location of fruit and berry areas near highways.

3. The processing channel provides for the sale of berries to processing enterprises immediately after harvest. The main disadvantage of the channel is the lowestprice offer for products.

4. Wholesale channel provides saleslarge parties. It allows the farmer to receive a significant amount of cash and invest it in growing a new crop. In addition, this channel allows you to focus resources on the production process, and the sale of products to wholesale intermediaries [26-29].

Promising sales channels include:

a) retail sales channel, which provides for the sale of not only produced but also processed products through retail chains (crucial are the costs of compliance with supply schedules and quality of supply, which are recouped by additional income from the sale of goods with high added value);

b) the target sales channel specializes in growing and selling certain products to order of processors, for example, canning fruits and berries (the advantages of the channel are associated with increased purchase price for the product due to its peculiarity);

c) the extended sales channel sells the main volume of products after the sales season, which provides for the availability of modern warehouses with refrigeration equipment in order to preserve the appearance and nutritional properties of products;

d) channel sales through supermarkets. This channel is promising due to the possibility of selling large volumes of products. 
But the increased requirements for quality parameters of products, volumes and terms of deliveries in combination with deferred payments create extremely limited opportunities to use this channel.

Thus, the existing sales channels are characterized by a small contribution to the creation of added value of products, while promising channels require additional funds to create modern infrastructure for storage of fruits and berries in combination with their processing, packaging, formation of commodity batches in accordance with the requirements of consumer demand.

Markets by criterion the ratio of supply and demand corresponds to the saturated type of markets and the potential type of markets.

SLM "rapid response commodity flow" (type of saturated markets) have the following characteristics:

- favorable conditions for commodity purchases (the situation of the buyer's market);

- increased competition between producers;

- short-term manifestations of unsatisfied demand.

Consider in more detail the last of these characteristics. Short-term manifestations of unsatisfied demand are characterized by the following signs:

- limited lifespan, the time interval of which usually lasts from several days to several weeks;

- difficulties in predicting the beginning and end of the manifestation;

- insignificant volumes of demand at a high level of space-time localization.

The problem of short-term demand is the lack of conditions for its satisfaction, namely:

a) the lack of tools for tracking the variability of demand, followed by the prompt transfer of information to participants in the logistics process;

b) the lack of flexible chains that are able to respond quickly to short-term demand. The development of mobile networks should be a tool to respond to short-term demand, in particular through the introduction of WMS management systems - solutions in conjunction with short-term demand monitoring. This measure will allow producers to increase sales of short-term demand by an average of $5-7 \%$ [28].

SLM "the formed commodity flow" (type of potential markets) corresponds to the situation of excess demand over supply (the existence of market niches). The following characteristics correspond to this type of markets:

- increased costs for the creation of market infrastructure for the development of market niches;

- fixed terms of existence of market niches from deliveries of trial commodity parties to an exit of market niches to the level of market equilibrium;

- priority influence of logistics on the effectiveness of the development of market niches (increased dependence of costs for the development of market niches on the choice of product range and logistics supply schemes).

Problematic is the characteristic associated with the priority impact of logistics on the effectiveness of the development of market niches. Overcoming the problem involves the involvement of logistics providers, the scale of whose business meets the conditions of customer demand by supplying through centralized logistics channels, which will provide standardization of management decisions and cover all leading consumption centers.

The conceptual approach to the use of the integrated model of logistics marketing proposed in the work allowed to establish the regularity of its simultaneous positive impact on the level of individual goods and product groups. In particular, the positive impact can be traced to indicators of conformity of characteristics of commodity deliveries to requirements of consumer demand: quantity of the executed orders, terms, volumes, the nomenclature of deliveries, periodicity of deliveries, flexibility of deliveries, etc. [30]. Examples of this relationship are summarized in Table 2. 
Table 2. Examples of positive effects of an integrated model of logistics marketing on the level of individual products and product groups *

\begin{tabular}{|c|c|c|}
\hline & $\begin{array}{c}\text { Measures (targets) to adapt logistics chains } \\
\text { to the problem characteristics of } \\
\text { commodity markets }\end{array}$ & $\begin{array}{c}\text { Problem area in relation to individual goods and } \\
\text { product groups. The level of overcoming the } \\
\text { problem }\end{array}$ \\
\hline \multirow{3}{*}{1.} & Market type: local markets. & \multirow{2}{*}{$\begin{array}{l}\text { Problem area: satisfaction of local demand in } \\
\text { relation to compliance terms of passage of goods on } \\
\text { logistics chains to existing standards. }\end{array}$} \\
\hline & \multirow{2}{*}{$\begin{array}{l}\text { Measures: development of supply standards } \\
\text { in combination with the optimization of the } \\
\text { number of units }\end{array}$} & \\
\hline & & $\begin{array}{l}\text { The level of overcoming the problem: complete } \\
\text { overcoming. }\end{array}$ \\
\hline \multirow{3}{*}{2.} & . & \multirow{2}{*}{$\begin{array}{l}\text { Problem area: lack of end-to-end planning of } \\
\text { commodity flows on maintenance of commodity } \\
\text { flows in the system "periphery - the leading center } \\
\text { of sale of goods". }\end{array}$} \\
\hline & \multirow{2}{*}{$\begin{array}{l}\text { Measures: creation of networks of regional } \\
\text { logistics centers for end-to-end planning of } \\
\text { trade flows on the basis of interterminal } \\
\text { organization of trade }\end{array}$} & \\
\hline & & $\begin{array}{l}\text { Level of overcoming the problem: partial } \\
\text { overcoming. }\end{array}$ \\
\hline \multirow[b]{3}{*}{3.} & Market type: national level markets. & \multirow{2}{*}{$\begin{array}{l}\text { Problem area: reliability of commodity deliveries } \\
\text { in relation to various spatial levels of consumer } \\
\text { demand. }\end{array}$} \\
\hline & \multirow{2}{*}{$\begin{array}{l}\text { Measures: creation of interconnected } \\
\text { networks of logistic intersections for complex } \\
\text { maintenance of distribution of commodity } \\
\text { flows, the basis of which should be the } \\
\text { mechanism of end-to-end planning of } \\
\text { commodity flows between national, regional } \\
\text { and local levels of distribution. }\end{array}$} & \\
\hline & & $\begin{array}{l}\text { Level of overcoming the problem: } \\
\text {-partial overcoming in relation to the indicators of } \\
\text { stability of terms and costs for logistics services of } \\
\text { goods; } \\
\text {-partial overcoming in relation to the execution of } \\
\text { orders. }\end{array}$ \\
\hline \multirow[b]{3}{*}{4.} & 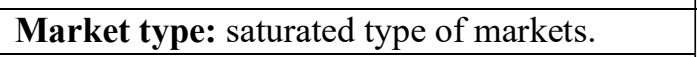 & \multirow{2}{*}{$\begin{array}{l}\text { Problem area: the level of flexibility in the supply } \\
\text { of goods and product groups. }\end{array}$} \\
\hline & \multirow{2}{*}{$\begin{array}{l}\text { Measures: development of networks of } \\
\text { mobile logistics chains of commodity } \\
\text { markets. }\end{array}$} & \\
\hline & & $\begin{array}{l}\text { Level of overcoming the problem: } \\
\text { partial overcoming in the context of short-term } \\
\text { unmet demand as a result of the use of mobile }\end{array}$ \\
\hline \multirow{3}{*}{5.} & $\begin{array}{l}\text { Market } \\
\text { niches). }\end{array}$ & \multirow[t]{2}{*}{$\begin{array}{l}\text { Problem area: correspondence of commodity } \\
\text { deliveries to the scale of consumer demand. }\end{array}$} \\
\hline & \multirow{2}{*}{$\begin{array}{l}\text { Measures: involvement of logistics providers } \\
\text { in the comprehensive provision of logistics } \\
\text { services, the scale of which corresponds to } \\
\text { the consumer demand of market niches. }\end{array}$} & \\
\hline & & $\begin{array}{l}\text { Lev } \\
\text { over }\end{array}$ \\
\hline
\end{tabular}

Source: author's development

Conclusions. The proposed conceptual scheme of logistics and marketing interaction, which consists in interdependent and interrelated consideration of the marketing factor at the stage of building logistics chains and the logistics factor in the marketing decision-making process provides an opportunity to use this interaction in forecasting and pre-project developments. The research allows us to state the selective influence of the integrated model of logistics marketing on changes in the characteristics of commodity markets. This refers to the characteristics that involve large-scale changes in the parameters of commodity supply and marketing.

The proposed methodological approach acquires increased relevance in the process of implementing radical transformation changes in the strategic commodity markets associated with the diversification of foreign markets, the formation of complete supply chains, innovative development of priority economic activities and others. The pattern is defined simultaneous positive impact of the proposed mechanism on overcoming problem areas at the level of individual products and product groups allows us to argue about its high potential effectiveness at the level of commercial decision-making. 


\section{REFERENCES}

1. Korobkov, V. (2007). Market aspects of the relationship between marketing and logistics. Logistika, 3, 10-11. [in Russian]

2. Nikishyna, O.V., Andrieieva, N.M., \& Lozova, T.P. (2019). Assessment of indicators of responsible consumption and production in Ukraine in the context of "green" logistics. The European Journal of Economics and Management, 1(5), 278-287. [in Ukrainian]

3. Bauersoks, D. Dzh. (2004). Logistics: an integrated supply chain. M.: ZAO «Olympbiznes». [in Russian]

4. Kristofer, M., \& Pek Kh. (2003). Marketing logistics. Oksford: Elsevier ButterworthHeinemann. [in Ukrainian]

5. Kristofer, M. (2004). Logistics and supply chain management. SPb.: Piter. [in Russian]

6. Lindera, M. R. (1999). Management of supplies and reserves. Logistics. SPb.: Polihon. [in Ukrainain]

7. Stok, Dzh. R., \& Lambert, D.M. (2005). Strategic logistics management. M.: INFRA-M. [in Russian]

8. Mirotin, L.B., Tashbaev, Y.E., \& Kasenov, A.G. (2002). Logistics: customer service. M.: INFRA-M. [in Russian]

9. Hadzhynskyi, A. M. (2010). Logistics: textbook for universities. M.: Dashkov i K. [in Ukrainian]

10. Krykavskyi, Ye. V. (2000). Integration of marketing and logistics in management systems. Visnyk Derzhavnoho universytetu "Lvivska politekhnika", 416, 52-62. [in Ukrainian]

11. Krykavskyi, Ye. (2007). Logistics and marketing: points of interaction. Lohistyka, 10, 34 37. [in Ukrainian]

12. Chukhrai N., \& Hirna, O. (2007). Formation of the supply chain: questions of theory and practice. Lviv: «Intelekt-Zakhid». [in Ukrainian]

13. Oklander, M. A. (2008). Contours of economic logistics. K.: Naukova dumka. [in Russian]

14. Fedosieieva, H. (2019). Sustainable development of agricultural producers is a condition for their successful functioning in the world market. Baltic Journal of Economic Studies, 5(1), 218-223. https://doi.org/10.30525/2256-0742/2019-5-1-218-223

15. Serdiuk T.M. (2011). System of indicators of efficiency of marketing management of commodity flows. Visnyk Khmelnytskoho natsionalnoho universytetu. Seriia: Ekonomichni nauky, 6, 182-186. [in Ukrainian]

16. Camilleri, M. A. (2018). Market segmentation, targeting and positioning. In Travel marketing, tourism economics and the airline product (pp. 69-83). Springer, Cham.

17. Svetunkov, S.G. (2016). Methodological problems of multilevel competition theory. SPb.: Izdatel'stvo «Levsha Sankt-Peterburg». [in Russian]

18. Irtyshcheva, I., Ponomarova, M., \& Dolzhykova, I. (2019). Conceptual fundamentals of development of the food security system. Baltic Journal of Economic Studies, 5(2), 57-64. https://doi.org/10.30525/2256-0742/2019-5-2-57-64

19. Tarakanov, N. L. Osipov, V.N., \& Rastorguev Y. E. (2009). Characteristics of typical logistics modes of product sales in an integrated model of logistics marketing. Vodnye puti Rossii: stroitel'stvo, ekspluatatsiya upravlenie: materialy Mezhdunarodnoi nauchno-prakticheskoi konferentsii (pp. 414-421). Sankt-Peterburg: FGOU VPO Sankt-Peterburgskii universitet vodnykh kommunikatsii [in Russian]

20. Pavlov, V.I., \& Bortnik, S.M. (2005). Transport and logistics complex of the region: integration processes. Lutsk: Nadstoria. [in Ukrainian]

21. Theory of growth poles and development centers. Studme.org. Retrieved from https://studme.org/106068/geografiya/teoriya_polyusov_rosta_tsentrov_razvitiya [in Russin]

22. Tarakanov, N.L. (2013). Regional logistics systems: problems of formation and development. Odessa: Interprint. [in Russian] 
23. Nikishyna, O., Lozova, T., \& Tarakanov, M. (2020). Formation and regulation of efficient logistics chains of the fruit and berry market of Ukraine. European journal of economics and management, 1(6), 67-76.

24. Holovko, I. (2013). Profit, sweet to the taste. Visnyk.com. Retrieved from http://www.visnuk.com.ua/ua/pubs/id/5574 [in Ukrainian]

25. Decker, R., \& Stummer, C. (2017). Marketing management for consumer products in the era of the internet of things. Advances in Internet of Things, 7(3).

26. Nikishyna O., Bondarenko S., \& Zerkina O. (2018). Methodical provisions for evaluating the effectiveness of agrarian producers and their cooperative associations in the production and logistics chain. Baltic Journal of Economic Studies, 4(5), 209-216. https://doi.org/10.30525/22560742/2018-4-5-209-216

27. Sakovska, O. (2020). Agricultural cooperation: experience of foreign countries for Ukraine. Baltic Journal of Economic Studies, 6(1), 118-124. https://doi.org/10.30525/22560742/2020-6-1-118-124

28. Monin, D. (2007). Why the warehouse needs WMS: an example from practice. Transport $i$ logistika, 2, 40-42. [in Russian]

29. Koval, V., Prymush, Y., \& Popova, V. (2017). The influence of the enterprise life cycle on the efficiency of investment. Baltic Journal of Economic Studies, 3(5), 183-187. doi:10.30525/2256-0742/2017-3-5-183-187

30. Greiz, G.M., Kuzmenko, Yu. G., \& Markovskii, V.A. (2013). Improving supply chain research methods based on GAP analysis. Vestnik YuUrGU. Seriya «Ekonomika i menedzhment», 1(7), 161-164. [in Russian] 